Article

\title{
EU Single Market(s) after Brexit
}

\author{
Michelle Egan \\ School of International Service, American University, Washington, DC 20016, USA; E-Mail: megan@american.edu
}

Submitted: 10 March 2019 | Accepted: 5 June 2019 | Published: 16 September 2019

\begin{abstract}
This article focuses on the European single market, which has been one of the central issues in terms of the impact of Britain's withdrawal from the EU. As the aim of the single market project is to open the internal borders of the EU to the free movement of goods, services, capital, and labor to create cross-jurisdictional markets, the economic and political effects of Brexit will be widespread, if not yet fully understood, outside the British polity. The article looks at the current state of the single market, then highlights the impact of British withdrawal on economic governance, focusing on different market freedoms, given the degree of trade interdependence and integrated supply chains that have evolved in response to changes in goods and services. One of the lessons from Brexit negotiations is the importance of distinguishing between different single market(s) when assessing the impact of British 'exit' on member states. The concluding section focuses on the political safeguards of market integration to manage the relationship between the UK and EU, to illustrate how judicial, market, and institutional safeguards create options and constraints in mitigating the effects of 'exit'.
\end{abstract}

\section{Keywords}

Brexit; European Union; market access; market integration; single market; safeguards

\section{Issue}

This article is part of the issue "The Impact of Brexit on EU Policies", edited by Ferdi De Ville (Ghent University, Belgium) and Gabriel Siles-Brügge (University of Warwick, UK).

(C) 2019 by the author; licensee Cogitatio (Lisbon, Portugal). This article is licensed under a Creative Commons Attribution 4.0 International License (CC BY).

\section{Introduction}

The outcome of the 'Brexit' referendum of 23 June 2016 generated shockwaves across Europe. Three years after the Brexit referendum radically different and largely incompatible views have emerged regarding options for the British economy as the 'exit' deadline has been extended. These options have ranged from what news media have dubbed a 'soft' Brexit, in which Britain would retain close ties with the EU, to a 'hard' Brexit, where the country would sever many economic and political connections and relinquish access to the single market (Grant, 2018). While the prevailing debates have centered around the degree to which Britain should (or not) retain access to the single market and customs union, what is increasingly clear is that untangling the economic relationship, given the mass of legislative commitments to foster the free movement of goods, capital, services and labor, will be difficult, due to the embeddedness of European rules in shaping British markets.
This is especially significant as Britain is a key player in the development of the single market, especially prior to the financial crisis, with its neoliberal model of policymaking. Such an approach is under increased scrutiny as Brexit arguably represents a backlash against this political economy model, which has thrown into sharp relief the cost of market integration in the absence of social protection (Hay, 2011). Brexit reflects a response to widening income gaps, stagnant wage growth, concentrated economic growth, low levels of productivity and declining job security (Hopkin, 2017; Innes, 2018). The unintended consequences of deepening market integration with increased labor and capital flows led many voters to perceive the single market as more of a liability in an era of Euroscepticism (Howarth \& Quaglia, 2017; Jones, Kelemen, \& Meunier, 2016).

While the ultimate effects on the single market are difficult to estimate; not only as the Brexit crisis is far from over, its impact will be felt long after the new economic relationship is in place. Though Britain has 
rarely been a 'pivotal outlier' on single market issues, pushing for liberalization with significant success, it has long felt that its institutional preferences have diverged from those of other member states, particularly France and Germany, due to their membership in the Eurozone (Dupont \& Moore, 2019). Recent debates in comparative political economy have, however, centered around the perception that Brexit will enable the EU to push the single market in a more social direction through changing the balance of regulatory debates in Europe and weakening the liberal market coalition (Howarth \& Quaglia, 2017; Luyendijk, 2016). This raises two key questions: 1) What are the potential effects of Brexit on the European single market?; and 2) What safeguards are in place to mitigate the risk exposure of Brexit on the single market, given the prospect of border controls disrupting integrated supply chains and creating new barriers for goods and services?

Most studies have not examined the differential impacts across the single market, treating the effects of Brexit as uniform. In fact, differences across the four freedoms in terms of existing levels of economic integration, as well as different modes of governance, will continue to shape market practices post-Brexit. The single market is not a singular entity, but a plurality of legal obligations that structures the regulatory activities of private economic actors as well as public actors and services in their provision of public goods. Degrees of change and adaptation to Brexit are not 'static' or 'uniform'; rather they are dependent on changing preferences and behaviour within domestic societies in response to different national growth models (De Ville \& Siles-Brügge, 2019). Drawing on the literature on the 'political safeguards' of federalism to illustrate how the EU is responding dynamically to Brexit, this article highlights how the EU27 are applying different protective mechanisms to mitigate the effects of Brexit. In doing so, the EU is making 'anticipatory adjustments' to protect the integrity of the single market.

The article is structured as follows: the first section outlines the current state of the single market, to highlight how this core economic-policy area, is increasingly differentiated, with variation in scope and depth of integration across different market freedoms as well as different institutionalized forms of cooperation. The heterogeneity of market integration results in several 'internal markets' rather than a single 'indivisible' package of tight rules and commitments (cf. Barnier, 2018; Howarth \& Sadeh, 2010). Member states will have varying responses to changes in their operating environment, within the constraints of the single market, barring them from some courses of action or requiring them to take specific action to deal with the fallout from Brexit. The second section looks at the potential effects of disruptions to trade patterns, fragmentation of supply chains, and restrictions in services, as those member states adversely affected by the withdrawal of one of the staunchest proponents of a single integrated market, face challenges to their own domestic markets. The third section focuses on 'federal' safeguards to explain how such intergovernmental safeguards protect the jurisdiction of different constituent units across Europe, limiting the destabilizing effects of British exit from the single market. In anticipating the post-Brexit relationship between the UK and EU, these safeguard measures include a mix of judicial, market, and institutional tools, and are evaluated here as a means of mitigating uncertainty and risk to the European single market. The conclusion considers the conditions under which the single market will prove durable by using those federal safeguards to manage markets and help fortify the union.

\section{State of the Single Market: Increasingly Differentiated}

The single market is considered one of the major achievements of European integration, promoting economic openness and extending the benefits of market access beyond the EU itself. The establishment of an internal market is stipulated by Article 3(3) of the Treaty of EU so the 'four freedoms' (goods, capital, services and labor) are constitutionally embedded into the Treaties. Initially, the process of market-making was intended to address economic protectionism by opening capital and labor to competitive market forces to reduce transaction costs and promote efficiency. While these efforts were aimed at removing tariff and customs barriers, this has been superseded by measures to address non-tariff barriers due to differences in regulations that can often be a source of trade friction; particularly if they restrict access to domestic markets. Many were discouraged by lack of progress; after all, the goal of a full economic union had not materialized, resulting in border controls, government subsidies to national industries, diverse industrial standards and regulations, as well as different banking, insurance and company requirements that impeded the circulation of goods and services.

Falling behind Japan and the United States in terms of competitiveness and productivity, the EU launched a single market initiative with a stated deadline of 1992. Built on the surge of neoliberal reforms, advocated by Britain, the resulting single market program to eliminate barriers received limited attention at the time. As the EU took renewed efforts to address persistent unemployment, slow growth and declining competitiveness through liberalizing trade and fostering coordination across a range of sectors and industries, there was often a gap between ambition and realization (Egan, 2015). In this case, a series of difficult measures were addressed to produce significant liberalization to open up highly protected markets, in areas such as airlines, insurance and securities, along with new innovative approaches that foreshadowed the 'better regulation agenda'.

Thus, market integration efforts also resulted in a range of governance mechanisms, from the top-down approach of harmonization in areas of high risk to more 
flexible approaches that encompass minimal harmonization through mutual recognition of rules, in which the EU relies heavily on a judicialized mode of governance, drawing on national courts as well as private litigants to pursue single market objectives (Egan \& Guimarães, 2017; Keleman, 2007). This has been supplemented by an increased use of alternative approaches to governance that encourage more voluntary or 'soft' forms of co-ordination yielding a problem-oriented analysis of the institutionalized modes of coordination.

Decoupling from the single market may depend on whether the legislation imposes heavier, more prescriptive and burdensome requirements or loose equivalence rules that provide for more national discretion. As the rules governing the single market are not 'defined in the same way nor is their relationship with other EU policies fixed or clear', constituent units are permitted considerable margin to determine speed, extent and density of regulations (Weatherill, 2017). Despite legal preference for uniformity of market rules, member states have chosen regulatory opt-outs, higher national standards, and substantive variation in domestic implementation post-1992. Such variation draws attention to the distinctive character of multilevel governance in the single market, and highlights how member state preferences can frame policy objectives. This has allowed Britain to shape ideas central to the single market including the current agenda for the digital single market, regulatory simplification, and opening of public procurement and audiovisual markets (Barnard, 2017; Egan, in press). Voting preferences in both the Council and Parliament also highlight that the British government has been far more content with policy outcomes in internal market issues, relative to many other policy areas (Hix, Hagemann, \& Frantescu, 2016). Voting data indicates Germany more consistently opposed legislation on single market issues, with Britain more supportive, and France subsequently opting for consensus if they had initially opposed specific single market issues (Hix et al., 2016). Thus, the single market has produced a range of measures by building active coalitions of member states including Britain, Sweden and the Netherlands that have consistently supported further liberalization (Barnard, 2017; Egan, 2015).

However, the salience of the single market has been sidelined by the Eurozone crisis, as emphasis was placed on crisis management instruments and sovereign debt obligations (Camisão \& Guimarães, 2017). The Commission saw the crisis as an opportunity to put the single market at the top of the agenda, as part of a two-tiered response that would promote economic governance and financial market supervision, boosting growth without debt. A major analysis of the single market, A New Strategy of the Single Market, undertaken by Mario Monti, acknowledges that there was a sense of complacency about the 'unfinished' business of the single market (Monti, 2010). Building on the Monti Report, the Commission published 'Towards a Single Market Act' detailing 50 proposals to reform the single market by the end of 2012, using the crisis as a catalyst for action (Camisão \& Guimarães, 2017, p. 229). Part of the problem is that the single market has been promoted through piecemeal reforms. Some of these have opened markets, but others have not due to a strategy of disjointed incrementalism which has featured small, successive and fragmented policy changes in a host of areas, covering a multitude of economic outcomes and objectives (Egan, 2015; Erixson \& Georgieva, 2016).

Although the single market has undoubtedly fueled competition, in some areas, it remains an aspiration rather than a reality (Monti, 2010, p. 7). More contentious market regulations meant that member states have limited incentive to engage in single market reform, despite the perceived benefits outlined in the new 'Costs of Non-Europe' reports commissioned by the European Parliament (European Parliament, 2017). The remaining barriers to cross-border integration, especially in services, including the energy sector, rail transport, telecoms, consumer insurance markets, banking and professional services, are difficult to eliminate, as services require regulation that differs from goods. While goods are tangible and subject to cross border checks, services are intangible, so that these barriers can impede mobility and the ability to establish commercial presence in another member state. In fact, single markets are dependent on further policy actions in an ever-widening range of fields with a direct impact on economic integration, including taxation, employment, industrial, transport, social policy, education, culture, public health, consumer protection, energy, and environment (Barnard, 2017). Such regulatory expansion has also brought increases in post-legislative litigation challenges to internal market measures with member states seeking annulment of legislative agreements (Armstrong, 2018; Weatherill, 2017). A striking outcome may be that member states are pushing to preserve their sovereignty, not through following the British 'exit' path out of the single market, but increasingly through litigating internal market measures at the post-legislative stage.

The growing flexibility in the laws that govern the single market-as well as the contentious nature of deliberations-highlights how the indivisibility and irreversibility that provided powerful lock-in mechanisms was gone long before Brexit. Differentiated integration has grown through a variety of mechanisms: through the proliferation of notification procedures to identify problems in the operation of single market rules; through policies that now operate within or outside the treaty framework, and through territorial differentiation that offers wide scope and institutionalization of non-member alignment with single market rules (Gstöhl, 2015; Howarth \& Sadeh, 2010). Nonetheless, in Brexit debates, the notion that the 'four freedoms, including the freedom of movement, are indivisible and inextricably linked' due to the 'indivisibility of the single market' masks the differential pace of liberalization as well as the 'concessions on free movement of persons (not goods, services, and capital)' 
that the EU conceded during the British renegotiation (Barnard, 2017, p. 203; cf. Barnier, 2018). While differentiation as a means of preserving national sovereignty has become a defining trait, Britain rejected Europe's effort to offer membership in flexible favorable terms. Yet despite the repatriation of competences to regain sovereignty, such regulatory autonomy will be tempered by the extent and specificity of internal market commitments set out in any future agreement. While the single market will remain in principle, indivisible, as member states defend the integrity of the single market, there exist various opt-outs and tailor-made arrangements for the European Economic Area (EEA) and European Free Trade Association states that provide a 'regulatory patchwork' of obligations for access to the internal market (Gstöhl, 2015). The subsequent outcome of Brexit will also establish some form of differentiation outside the scope of formal EU membership.

\section{Economic Effects of Brexit on European Single Market(s)}

The global context in which the single market now operates has fundamentally changed, moving away from economies of scale and mass production towards a knowledge and service economy based on product differentiation and global value chains (Erixson \& Georgieva, 2016). The prospect of trade diversion as well as damage to trading relationships has forced member states to evaluate prospects of alternative, competing legal, financial, regulatory and tax arrangements in the post-Brexit environment. Brexit-induced corporate reorganizations have pushed remaining member states to think hard about the differences between a single market in goods and services versus cross-border trade between distinct jurisdictions. In a major survey of businesses involved in supply chain management, $63 \%$ of EU businesses expect to move their supply chain out of Britain, while $40 \%$ of UK businesses expect that they will replace their EU partners with domestic suppliers as a result of Brexit (Chartered Institute of Procurement and Supply , 2017). Many European businesses indicated that the impending departure of Britain has already negatively impacted trade which has grown at a less dynamic pace than would be expected. The pound's fall against the euro has also worsened the sales outlook for manufacturers in exporting to Britain, given the loss of purchasing power in the UK (Deutscher Industrie- und Handelskammertag, 2018; Egan, in press). There is increased wariness in investing in British startups as it is not clear if they will be classified as European companies, which impacts the tax benefits that member starts can receive if they allocate funds to specific regions. New investment from the EU27 to Britain after the referendum is estimated to have declined by around $11 \%$, whereas British investment in the EU27 has seen a 12\% increase. Perceptions that there will be an increase in barriers to trade and $\mathrm{mi}-$ gration have led many firms to the 'offshoring' produc- tion and services to Europe (Breinlich, Leromain, Novy, \& Sampson, 2019; Harding \& Lewis, 2018; Inagaki, Lewis, \& Mace, 2019).

In manufacturing, the complex nature of supply chains has led companies to consider alternative transportation of component parts, renegotiation of supply chain contracts, and temporary closure of plants to avoid disruptions created by new tariffs and taxations. Most concerns focus on the disruptions to cash flow and justin-time methods. The high ratio of gross trade in relation to value-added suggests that much of British trade with Europe is connected to supply chains (Irwin, 2015). Given that many products cross back-and-forth into the EU multiple times during production, products will have to meet rules of origin requirements to determine that the product does not include a significant proportion of non-UK components. Though this may prove a problem for EU exporters as well, EU exporters are less reliant on UK inputs obtaining $1.5 \%$ from the UK compared to $9.3 \%$ of the UK's inputs which are sourced from the EU (Levell, 2018). The Dutch have estimated after Brexit that the number of import declarations will increase by 752,000 and the number of export declarations by 4.2 million; with costs of customs formalities for imports and exports between the Netherlands and Britain ranging from EUR 387.2 million to EUR 627.4 million per year (Lomas, 2018). Nontariff barriers also present a risk to specific industries, if they have a time sensitive product that is delayed at the border, potentially not reaching destinations in a condition to permit sale or usage. Sensitive goods such as food, pharmaceuticals and chemicals for example are subject to strict rules so that Europe will not want Britain to become a 'back door' route for third country market access without meeting EU product rules and requirements.

Several key German and British automotive companies have indicated that they would withdraw investment from Britain in the event of a hard Brexit (Lagenbacher, 2017). Not only does Britain represents a fifth of German auto exports, but the employment issue is also significant as German corporate subsidiaries employ 400,000 workers in Britain, while British companies employ 250,000 workers in Germany (Lagenbacher, 2017). Automotive investment in Britain has already collapsed from GBP 1.66 billion in 2016 to just GBP 322 million in first half of 2017 (Grey, 2018). While the Germany auto industry has stressed the integrity of the single market, Japanese auto companies such as Honda, Nissan and Toyota would not continue their operations if there is no profitability in Britain, as car companies avoid rule of origin requirements by using components from all European member states without penalties, regardless of where the component is manufactured or shipped (Harding \& Lewis, 2018). Businesses in the run up to the initial Brexit deadlines were stockpiling goods at record levels in order to offset the costs of delays; while overseas customers continue to divest themselves of reliance on British supply chains. Member states are bearing the burden of increased costs of providing more personnel 
for customs authorities in the Netherlands, France and Ireland, to track and physically examine goods entering the single market from Britain (Maxwell, 2018).

Across banking, insurance, investment firms, investment funds and financial market infrastructures, companies are considering changes in location and operations as the British domination of European financial markets-particularly where non-bank actors are concerned-will be impacted by their exclusion from the single market (Wright \& Bax, 2016). London accounts for more than $50 \%$ of the gross valued added of the total financial and insurance sector in Britain, resulting in a trade surplus with the EU of GBP 19.8 billion (Rhodes, 2018). Brexit will shrink European capital markets by roughly $25 \%$, so that even with the prospect of regulatory equivalence, only certain financial services, including investment, clearing and hedge funds may be included, while traditional bank activities such as retail deposits and commercial lending will be excluded from single market access (Fuller, in press, p. 2). The prospect has pushed select banks to shift some of their British operations to other major cities including Frankfurt, Paris and Dublin. More than 2.3 million are employed in the financial service industry in Britain. Financial services companies, including banks, insurance, and wealth management firms have moved assets worth USD 1 trillion from Britain; however, private equity and financial technology companies are less likely to relocate (EY, 2019). While British banks had hoped to keep passporting rights to continue selling their products and services after Brexit, the loss of mutual recognition for financial services impacts nonEuropean firms, notably American, Japanese and Swiss banks, that had used Britain as a foothold into the single market (Fuller, 2015; see Table 1). Certain member states see this as an opportunity to put pressure on British firms to shift operations to the EU to build up their capital markets. Yet concerns about financial instability revolve around London clearing houses, as approximately half of all euro transactions into foreign exchange takes place in Britain. While member states do not want British clearing houses to have access to European markets without EU oversight, they have been reluctant to cede further regulatory authority to Brussels. To avoid disruption, there are provisions to temporarily recognize clearing houses after Brexit if no transition is in place, but this is a stopgap solution to avoid rising trade costs for EU customers until euro denominated clearing takes place in the euro zone, once Britain becomes a non-EU state (Brunsford \& Stafford, 2018).

As the British financial system differs substantially from most other EU member states, Brexit changes little for the banking union agenda (Fuller, in press; Schelkle, 2018). The absence of Britain will have limited impact on the final set of rules for banking union. Britain had not engaged with these discussions as the financial ramifications from the Eurozone crisis had pushed British interests 'further away from other member states' (Thompson, 2017, p. 440). As capital markets remain frag- mented, and investment obstacles are still high, the single market had not achieved its stated goal. Prospects for capital market union are likely to be different as Britain was engaged in efforts to improve access to capital within the EU. Capital markets are relatively underdeveloped, hindering European firm's ability to fund growth to meet their borrowing and investment needs (European Commission, 2015; Fuller, in press). Reflecting an effort to shift towards market-based banking, Britain would benefit significantly from capital markets union due to its deep, liquid, and innovative financial markets (Fuller, in press). While Britain was supported by those member states with similar financial systems, including Ireland, Netherlands, and Luxembourg, as well as those that wanted more access to capital unavailable in their own domestic financial markets, France and Germany were more opposed to the undermining of their bank financing model. Framed as part of the single market project, banking union and capital markets union in Europe are at varying stages of development. While Brexit has taken away one of the leading voices for financial services liberalization, it may mean that Eurozone members will have more power to drive economic and financial policy in the bloc. In fact, the presence of Britain has been important for countries outside the Eurozone, as Denmark and Sweden have relied on the largest non-euro member of the bloc to protect their position on banking union.

In services, such as insurance, business, and pension services, Brexit will result in new restrictions on the ability to offer cross-border services, generating pressure for relocation for those that require the establishment of a commercial presence within the single market as a condition of market access (Lowe, 2018).

Member states impose different rules, whether across pension management, insurance, securities, or accounting services, in part as the single market in services is only partially liberalized (Egan, 2015). As a result, European branches of non-EU companies are not allowed to trade across the EU under host-state rules so locally established branches, subsidiaries or offices of a British owned-and controlled company lose the automatic benefits of rights of establishment, recognition of qualifications and the right to temporary movement of workers into the host country. Many cross-border services will face new restrictions. Britain leaving the single market will also have knock on effects for access to foreign lending, especially for countries such as Malta, Netherlands and Ireland (Lowe, 2018). Losing such a large and influential member may also impact reform as European markets, particularly in the service sector, which is not as open to competition as often depicted (cf. Lowe, 2018). Italy, Spain and Portugal have made some ambitious-and politically costly-changes to their labor markets. Germany and France have undertaken 'selective' liberalization in many service sectors and are now championing an industrial policy to create European champions to compete with the United States and China (Egan, 2015). Some member states have 
Table 1. Single markets.

\begin{tabular}{|c|c|c|c|c|c|}
\hline $\begin{array}{l}\text { Market } \\
\text { Freedoms }\end{array}$ & $\begin{array}{l}\text { Evaluation of } \\
\text { barriers in } \\
\text { single market } \\
\text { (composite } \\
\text { indicator)* }\end{array}$ & $\begin{array}{l}\text { UK position on } \\
\text { single market }\end{array}$ & $\begin{array}{l}\text { Effect of 'hard' Brexit } \\
\text { on Britishmarket }\end{array}$ & $\begin{array}{l}\text { Industry } \\
\text { relocation } \\
\text { due to } \\
\text { market } \\
\text { access }\end{array}$ & $\begin{array}{l}\text { Effect of 'hard' Brexit } \\
\text { on Single market }\end{array}$ \\
\hline Goods & Low & Support & $\begin{array}{l}\text { - Disruption to supply } \\
\text { chains } \\
\text { - Loss of cabotage in } \\
\text { road and airline sector } \\
\text { - Increased customs } \\
\text { formalities } \\
\text { - Application of Tariffs } \\
\text { - Testing of agricultural } \\
\text { products (SPS) for } \\
\text { market access }\end{array}$ & $\begin{array}{l}\text { Automotive } \\
\text { (high) }\end{array}$ & $\begin{array}{l}\text { - Disrupt supply chains } \\
\text { - New customs } \\
\text { formalities } \\
\text { - Less focus on } \\
\text { regulatory reform and } \\
\text { simplification }\end{array}$ \\
\hline Capital & $\begin{array}{l}\text { Medium } \\
\text { (taxation and } \\
\text { customs } \\
\text { barriers) }\end{array}$ & $\begin{array}{l}\text { Support (except } \\
\text { tax harmonization } \\
\text { and specific } \\
\text { post-crisis } \\
\text { financial rules) }\end{array}$ & $\begin{array}{l}\text { - Movement of financial } \\
\text { assets out of UK market } \\
\text { - Dependent on } \\
\text { recognition and access } \\
\text { of clearing houses and } \\
\text { trading venues } \\
\text { - Shift of euro- } \\
\text { transactions to } \\
\text { member states }\end{array}$ & $\begin{array}{l}\text { Financial } \\
\text { Services } \\
\text { (medium) }\end{array}$ & $\begin{array}{l}\text { - Lack of strong capital } \\
\text { markets } \\
\text { - Less access to liquid, } \\
\text { innovative capital } \\
\text { markets } \\
\text { - Decline in equity } \\
\text { markets and pension } \\
\text { funds } \\
\text { - Less support for } \\
\text { capital markets union } \\
\text { - Dominance of banking } \\
\text {-based model of finance }\end{array}$ \\
\hline Services & $\begin{array}{l}\text { High } \\
\text { (recognition of } \\
\text { professions; } \\
\text { Digital single } \\
\text { market; } \\
\text { Collaborative/ } \\
\text { gig economy) }\end{array}$ & Support & & $\begin{array}{l}\text { Healthcare } \\
\text { (high); } \\
\text { technology } \\
\text { (medium) }\end{array}$ & $\begin{array}{l}\text { - Adequacy decision for } \\
\text { data flows. } \\
\text { - Passporting for } \\
\text { financial services } \\
\text { - Euro transactions } \\
\text { - Rights of establishment }\end{array}$ \\
\hline $\begin{array}{l}\text { Labor } \\
\text { (FOM) }\end{array}$ & $\begin{array}{l}\text { High (free } \\
\text { movement and } \\
\text { right to reside) }\end{array}$ & $\begin{array}{l}\text { Restrict labor } \\
\text { mobility } \\
\text { (post-Brexit) }\end{array}$ & $\begin{array}{l}\text { - Loss of labor force } \\
\text { for healthcare and } \\
\text { consumer services } \\
\text { - Labor shortages }\end{array}$ & $\begin{array}{l}\text { Low skill } \\
\text { labor } \\
\text { migration } \\
\text { curbed }\end{array}$ & $\begin{array}{l}\text { - Loss of employer of } \\
\text { last resort }\end{array}$ \\
\hline
\end{tabular}

Note: * Composite of indicators including infringement proceedings, solvit cases, expert survey, reports from Copenhagen Economics, European Parliament Costs of Non-Europe report.

made good use of exceptions, justifying obstacles to free movement in services, even as the British have endorsed legal challenges to remove restrictions, reflecting their focus on competitiveness rather than market protection (Barnard \& Butlin, 2018). With the politicization of the single market and the widening regulatory and economic development associated with Eastern enlargement, fears of increased regulatory competition and social dumping in the wealthier member states put them at odds with the British liberalization agenda (Crespy, 2010; Luyendijk, 2016).

Brexit may likely change the balance of regulatory debates in Europe. There are concerns that the ab- sence of British 'voice' will revive old 'statist' ambitions at the European level. While levels of regulation in product and labor markets have converged towards a British neoliberal approach, Germany and France advocate for a more active industrial policy to promote European champions (French Ministry for the Economy and Finance \& German Federal Ministry for Economic Affairs and Energy, 2019). Recent calls for a strategic approach to technology, screening of foreign direct investment, and the surge of bank interventions in response to the financial crisis highlight this strategic re-orientation. Those advocating a 'social Europe' would no longer face opposition from Britain which has staunchly opposed 
such regulatory rules for working conditions given its more flexible labor market model (cf. Copeland, 2019). However, Sweden and the Netherlands stand to lose a powerful pro-business ally, as Brexit tilts Europe towards strengthening issues of social, environmental and labor rights. The coalition of liberal market economies is expected to become weaker, while southern member states will be further marginalized, as they depend heavily on access to the British labor market as an employer of last resort.

Despite British commentary about the intrusiveness of European regulations, as well as continual refrains about excessive 'red tape', there are indications that British state capacities would be strengthened postBrexit (Her Majesty's Government UK, 2018). Rather than a more 'competitive' regime, vying for capital and markets through 'a bonfire of EU regulations', Britain will need to create new institutional and regulatory frameworks for implementing new domestic laws or alignment with specific policy areas of the EU. British political economy will need to revitalize its administrative capacity to deal with the delegation of regulatory responsibilities after decades of state shrinking to address practical questions about how Britain is to be governed after Brexit (Innes, 2018).

Within Europe, Ireland, Cyprus and the Netherlands are the most exposed economies given high volumes of cross-border trade (Bollen, Meijerink, \& RojasRomagosa, 2016; Egan, in press). For the Netherlands, Belgium, Austria and Ireland, the economic impact will be the most significant as their exports to Britain amount to around $10 \%$ of their gross domestic product (GDP). In the Netherlands, estimates indicate that Brexit will result in a drop of $1.2 \%$ of GDP over fifteen years with income loss amounting to 1 billion euros by 2030 for the Netherlands (Bollen et al., 2016). Similar reports for Ireland, suggest that there could be a $30 \%$ drop in exports with total sales in goods and services falling by $4 \%$ of GDP as a result of Brexit (Bergin, Economides, GarciaRodriguez, \& Murphy, 2019). The effects will vary within member states, as regions and municipalities weigh the impact of Brexit on their trade, agriculture, and fisheries sectors and negative effects on transportation and energy resources (Bollen et al., 2016; European Committee of Regions, 2018). The European Parliament has called for financial support for impacted regions, given the costs of instituting new land and sea borders, while the Committee of the Regions has lobbied for greater flexibility in state aid rules, as a result of possible changes in the destination of foreign direct investment and disruptions in trade patterns (Joulaud, 2019; van Nistelrooij \& Joulaud, 2018).

\section{Safeguards for the Single Market}

Markets are inherently imperfect, so the impacts of Brexit will vary, depending not only on the terms of the withdrawal agreement and the future trading rela- tionship, but the type of internal market(s) that exist within the EU. While the overall macroeconomic impact of Brexit is difficult to quantify, the provisions for institutional safeguards are designed to maintain the integrity of the single market in the post-Brexit environment. Although different sectors will be subject to economic stress, given the need to absorb the changes wrought by Brexit, the single market has proved to be remarkably durable in the past (Egan, 2015). Despite resistance by many member states to contributing additional resources to make up for the shortfall from British budgetary contributions, the legacy of the credit induced boom and structural imbalances in trade and capital flows created tensions derived from different growth models within the single market (Caporaso, 2018). Increased political contestation surrounds the single market, as certain member states seek to slow down economic liberalization in the face of domestic political resistance. Yet, even without Brexit, the heterogeneity of member state preferences has made collective action difficult in many areas of the single market. Deadlock and prolonged negotiation over issues from posted workers, taxation, patents, company statutes to cross-border takeovers, have stood in the way of a truly open market (Monti, 2010). Europe has shifted towards a more disjointed incrementalism, through a series of discrete reform initiatives, where a 'complex web of regulations, administrative rules, national discretion, and partial freedoms' is at odds with discursive debates that assume adherence to all four freedoms based on a uniform, complete 'single' market (cf. Erixson \& Georgieva, 2016).

While EU member states tout the centrality of the four freedoms, their willingness to support the single market is tied to the strength of political safeguards to protect their respective national interests (Glencross, 2008). Member states are keen to avoid an extended period of uncertainty that damages confidence and impacts both domestic and inward investment in the rest of the EU (Irwin, 2015). As Europe confronts intended and unintended effects posed by British 'exit', three types of safeguards drawn from comparative federalism can be identified in terms of how they might sustain credible commitments towards the single market in the face of centrifugal pressures (Keleman, 2007). As Table 1 highlights, this is especially important given the selective and partial nature of the single market, as EU member states will not allow the UK to 'cherry-pick' from the EU acquis, single market or other domains. Since the free movement of goods does not follow precisely the same model as the free movement of persons, and legislative activity varies by sector, the potential impact of Brexit differs across territories and markets. Trade exposure and trade reliance can lead to potentially unexpected 'negative' and 'positive' externalities, leading to efforts at ex ante political control as well as ex post legal control to monitor and safeguard the single market.

Some political safeguards are designed to prevent British companies from gaining a post-Brexit compet- 
itive advantage by undercutting regulations and making changes in taxation, state aid, environmental standards and employment rights that would have negative consequences for the competitiveness of the single market (Barker \& Brunsden, 2018). The EU will use its jurisdictional boundaries over markets to continue to shape regulatory practices in neighboring states in such areas as pharmaceuticals, finance, and data privacy (Farrell \& Newman, 2019). Much like trade policy negotiations, Europe's internal institutional capacities shape its strategic capabilities and behavior, enhancing its relative bargaining position through 'market power' (Damro, 2012). Such action may coerce Britain into complying with European rules given that global firms may leave specific jurisdictions due to the diverging market structure and adverse restrictions placed on their operations. Jurisdictional expansion increases the attractiveness of the European 'home' market as the 'spill-over' via the EEA, of neighboring Norway, Liechtenstein, and Iceland creates an institutionally differentiated mode of horizontal integration, that is inspired by, but less ambitious than the internal market (Gstöhl, 2015). This is not dissimilar to the Irish backstop, where structural safeguards are in place in the EU-UK withdrawal agreement to ensure that there is no 'hard border' after Brexit as Britain is outside a customs union and internal market. The agreement means that Northern Ireland will remain aligned with elements of the single market to ensure continued cooperation between North and South, avoiding crossborder trade problems, while allowing the UK during an unspecified interim period to remain within the customs territory, if no alterative arrangements are implemented. This differentiated mode of integration serves to provide structural safeguards for the Irish economy through regulatory alignment, if a future trade deal is insufficient to avoid border checks and controls between the UK and EU, and reinforces European influence due to the prospect that Northern Ireland would remain inside the single market and the customs union (Hayward \& Phinnemore, 2018). This safeguard is designed to reduce cross-border barriers by remaining within parts of acquis, so that customs codes, regulations and value added tax are aligned, with the customs union also addressing the rules of origin issue.

The EU may also deploy existing judicial instruments more aggressively to ensure market stability, as it has a wide range of formal powers to deal with non-compliance with European law and obligations. The European Court of Justice (CJEU) has continued to tighten control over member state compliance, while the Commission has strengthened its enforcement capacities and impose financial penalties on member states that disregard judicial rulings (Keleman, 2007). Judicial safeguards are enhanced by decentralized enforcement in which private parties may bring action if they are harmed by member state 'shirking' their community obligations. This protects the integrity of the single market by providing judicial safeguards that continuously ad- dress breaches of market freedoms (Egan \& Guimarães, 2017). It will not countenance institutional opt-outs that Britain has procured in the past, whether emergency breaks for migrants, financial transactions tax or exclusion from the euro as this undermines the integrity of the single market. In fact, the withdrawal agreement provides for legal safeguards that allow for the continuation of the jurisdiction of the CJEU beyond the transition period, as issues related to European law would be referred to the CJEU which would have the same legal effect in the UK as it would in the member states. Though this is a deeply divisive issue in British politics, 'not much escapes the reach of the law of the EU's internal market' (Weatherill, 2017, p. 142). This discursive struggle over deference to legal authority is a necessary foundation for the EU's political authority and legitimacy, to ensure a uniform legal interpretation across the entire internal market (Glencross, 2008).

This is accompanied by calls for market safeguards in which Europe can extend the compromises inherent in 'embedded liberalism', to compensate those interests that suffer losses from the disruptive effects of Brexit through trade adjustment assistance programs offsetting disruptions in trade patterns (Ruggie, 1982). Demands for Brexit assistance have emerged from municipalities and regions, given the costs of increased border controls and security. In response, Europe has adopted 'no deal' contingency measures to safeguard key single market areas including customs facilitation, financial services, and air transport, through provisions for temporary conferral and access rights to protect their own citizens and markets (Government of Ireland, 2018). So far, the EU has adopted multiple preparedness notices as well as legislative proposals that are temporary in nature, if there is a no deal. Some compensatory trade adjustment assistance is also available for those sectors, such as fishing, that will see the closure of access rights to British waters. In the face of no deal, effective action is uncertain, given that Brexit has proceeded without a reckoning of the spillover effects on market access and border controls. No matter what the final shape of future relations between the EU and the UK will be, the British have bolstered 'single market safeguards' as member states have collectively agreed that the four freedoms are 'indivisible.' Ironically, Brexit is highlighting the statutory obligations of the single market, while also making it more difficult to pursue close regulatory alignment with single market and customs rules. The structural faultlines in Britain's soon to be expired membership rest on a political economy model that increasingly diverges from much of the rest of the EU. The prospect of one of the biggest single market advocates being absent means that the neoliberal, market-driven growth model pursued during decades of growth will likely shift to a more protective one, anchored by French and German concerns about addressing competitiveness through more direct intervention and market concentration that 'protects Europe'. 


\section{Conclusion}

At this time of writing, the terms of withdrawal from the single market-if Britain wants a deal-are set from the perspective of the EU. The amount of time spent in negotiations since the referendum highlight how Brexit was always going to be an asymmetrical process that might be termed 'accession in reverse'. While Britain's departure has generated widespread analysis about the domestic effects of leaving the single market given the degree of trade interdependence and integrated supply chains in goods and services, less attention has been given to the implications of Brexit for the EU. Yet how member states will be impacted by the departure of the EU's secondlargest economy, the key global financial center, and the largest service economy will vary, depending on specific policy areas, export interdependence, and domestic responses to risk and uncertainty. The variation in regional and national exposure to Brexit across member states, as well as the differentiated forms and instruments of EU governance, including within the single market itself, means that specific challenges and destabilizing effects may be different across market freedoms. While experience with the single market may be direct and tangible for business and consumers, it may also affect devolved administrations that have responsibility for implementing European laws in specific fields, as well as administrative and regulatory agencies. All these actors will have to amend their networks, roles, and responsibilities due to Britain's changing relationship with the EU. The type of arrangement between the EU and UK will depend on addressing major cross-cutting issues for trade that, if given priority, may alleviate some of the negative effects.

Drawing on the literature on self-reinforcing federalism, the EU has pushed 'federal safeguards' to mitigate market effects, demarcating their regulatory authority, by not allowing Britain to 'cherry pick' elements of the single market and reiterating the indivisibility of the four market freedoms. As Table 1 illustrates, they have also used juridical safeguards to ensure compliance with any negotiated withdrawal agreement, as well as fiscal safeguards for those adversely affected by British exit. Due to concerns over 'regulatory dumping' the EU has adopted contingency plans-as have member statesaimed at safeguarding existing regulatory, institutional and political obligations in relation to the single market. The safeguards have the express purpose of securing the desired benefits of keeping the single market functioning as the difficulty posed by 'secession' from a tightly integrated 'federal' type system is that it creates incentives for shirking and transgressions by the British state. The institutional design of federalism shows how different safeguards protect both the ability of the single market to continue to achieve the goals for which it was designed and its long-term sustainability.

\section{Acknowledgments}

A CFR (IAF) Fellowship provided support for my research.

\section{Conflict of Interests}

The author declares no conflict of interests.

\section{References}

Armstrong, K. A. (2018). Regulatory alignment and divergence after Brexit. Journal of European Public Policy, 25(8), 1099-1117.

Barker, A., \& Brunsden, J. (2018). EU seeks powers to stop post-Brexit bonfire of regulation. Financial Times. Retrieved from https://www.ft.com/content/ 9052ed50-06d5-11e8-9650-9c0ad2d7c5b5

Barnard, C. (2017). Brexit and the EU internal market. In F. Fabbrini (Ed.), The law and politics of Brexit (pp. 201-220). Oxford: Oxford University Press.

Barnard, C., \& Butlin, S. (2018). Free movement vs fair movement: Brexit and managed migration. Common Market Law Review, 55(3), 203-226.

Barnier, M. (2018). Speech by Michel Barnier at the European American Chamber of Commerce. European Commission. Retrieved from http://europa.eu/rapid/ press-release_SPEECH-18-4452_en.htm

Bergin, A., Economides, P., Garcia-Rodriguez, A., \& Murphy, G. (2019). Ireland and Brexit: Modelling the impact of deal and no-deal scenarios. Quarterly Economic Commentary: Special Articles, 2019, 1-32. https://doi.org/10.26504/qec2019spr_sa_bergin

Bollen, J. C., Meijerink, G. W., \& Rojas-Romagosa, H. A. (2016). Brexit costs for the Netherlands arise from reduced trade (Policy Brief No. 07). The Hague: CPB Bureau of Economic Policy Analysis.

Breinlich, H., Leromain, E., Novy, D., \& Sampson, T. (2019). Voting with their money: Brexit and outward investment by UK firms. Vox. Retrieved from https://voxeu.org/article/brexit-and-outwardinvestment-uk-firms

Brunsford, J., \& Stafford, P. (2018). EU pledges access to UK clearing houses in no deal Brexit. Financial Times. Retrieved from https://www.ft.com/content/ 045fc67a-db9f-11e8-9f04-38d397e6661c

Camisão, l., \& Guimarães, H. (2017). The commission, the single market and the crisis: The limits of purposeful opportunism. Journal of Common Market Studies, 55(2), 223-239.

Caporaso, J. (2018). Europe's triple crisis and the uneven role of institutions: The euro, refugees and Brexit. Journal of Common Market Studies, 56(6), 1345-1361.

Chartered Institute of Procurement and Supply. (2017). EU businesses say goodbye to UK suppliers as Brexit bites into key relationships. Chartered Institute of Procurement and Supply. Retrieved from https://www.cips.org/en/who-we-are/news/eu- 
businesses-say-goodbye-to-uk-suppliers-as-brexitbites-into-key-relationships

Copeland, P. (2019). Why Brexit will do little to change the political contours of the European social dimension. Politics and Governance, 7(3), 30-39.

Crespy, A. (2010). When 'Bolkestein' is trapped by the French anti-liberal discourse: A discursiveinstitutionalist account of preference formation in the realm of European Union multi-level politics. Journal of European Public Policy, 17(8), 1253-1270.

Damro, C. (2012). Market power Europe. Journal of European Public Policy, 19(5), 682-699.

De Ville, F., \& Siles-Brügge, G. (2019). The impact of Brexit on EU trade policy. Politics and Governance, 7(3), 7-18.

Deutscher Industrie- und Handelskammertag. (2018). The impact of Brexit on German business. Berlin and Brussels: Deutscher Industrie- und Handelskammertag. Retrieved from https://www.dihk.de/ ressourcen/downloads/brexit-umfrage-02-18engl.pdf/at_download/file?mdate $=1519922059758$

Dupont, C., \& Moore, B. (2019). Brexit and the EU in global climate governance. Politics and Governance, 7(3), 51-61.

Egan, M. (2015). Single markets: Economic integration in Europe and the United States. Oxford: Oxford University Press.

Egan, M. (in press). Brexit and the single market. In J. Laible \& S. Greer (Eds.), EU after Brexit. Manchester: Manchester University Press.

Egan, M., \& Guimarães, M. H. (2017). The single market: Trade barriers and trade remedies. Journal of Common Market Studies, 55(2), 294-311.

Erixson, F., \& Georgieva, R. (2016). What is wrong with the single market? (Working Paper, No. 1). Belgium: European Centre for International Political Economy. Retrieved from https://ecipe.org/wpcontent/uploads/2016/02/5Freedoms-012016paper_fixed_v2.pdf

European Commission. (2015). Action plan on building a capital markets union (COM/2015/0468 final). Brussels: European Commission.

European Committee of Regions. (2018). Assessing the impact of the UK's withdrawal from the EU on regions and cities in EU27. Brussels: European Committee of Regions. Retrieved from https://cor.europa. eu/Documents/Migrated/news/impact-brexit.pdf

European Parliament. (2017). Mapping the costs of nonEurope 2014-2019 (PE 603.239). Brussels: European Parliamentary Research Service. https://doi.org/10. 2861/35381

EY. (2019). EY financial services Brexit tracker: Financial services firms put contingency plans in action as asset and job relocation continues to increase. $E Y$. Retrieved from https://www.ey.com/uk/en/ newsroom/news-releases/190320-fs-brexit-tracker

Farrell, H., \& Newman, A. (2019). Of privacy and power.
Princeton, NJ: Princeton University Press.

French Ministry for the Economy and Finance, \& German Federal Ministry for Economic Affairs and Energy. (2019). A Franco-German manifesto for a European industrial policy fit for the 21st century. Retrieved from https://www.bmwi.de/Redaktion/DE/ Downloads/F/franco-german-manifesto-for-aeuropean-industrial-policy.pdf?_blob=publication File\& $\mathrm{v}=2$

Fuller, G. (2015). Who's borrowing? Credit encouragement vs. credit mitigation in national financial systems. Politics \& Society, 43(2), 241-268.

Fuller, G. (in press). Subtraction by subtraction? Brexit and its impact on the common European financial space. In J. Laible \& S. Greer (Eds.), EU after Brexit. Manchester: Manchester University Press.

Glencross, A. (2008). Consensus to contestation: Reconfiguring democratic representation in the European Union in the Light of 19th century United States democratization. Democratization, 15(1), 123-141.

Government of Ireland. (2018). Preparing for the withdrawal of the UK from the European Union on 29 March 2019. Dublin: Government of Ireland. Retrieved from https://www.dfa.ie/media/dfa/eu/ brexit/brexitcontingency/No-Deal-BrexitContingency-Action-Plan-December-18.pdf

Grant, C. (2018). 'Canada', 'Norway' or something in between? London: Center for European Reform. Retrieved from https://www.cer.eu/sites/default/files/ insight_CG_26.1.18.pdf

Grey, C. (2018). The business and economic effects of Brexit matter: Ask Brexiters. The Brexit Blog. Retrieved from http://chrisgreybrexitblog.blogspot. com/2018/10/the-business-and-economic-effectsof.html

Gstöhl, S. (2015). Models of external differentiation in the EUs neighbourhood: An expanding economic community? Journal of European Public Policy, 22(6), 854-870.

Harding, R., \& Lewis, L. (2018). Corporate Japan despairs at UK's lack of clarity over Brexit. Financial Times. Retrieved from https://www.ft.com/content/ 37e87630-a9eb-11e8-94bd-cba20d67390c

Hay, C. (2011). Pathology without crisis? The strange demise of the Anglo-liberal growth model. Government and Opposition, 46(1), 1-31.

Hayward, K., \& Phinnemore, D. (2018). The white paper and the Irish dimension: Enough to avoid a hard border? Queen's Policy Engagement. Retrieved from http://qpol.qub.ac.uk/uk-white-paperirish-dimension-border

Her Majesty's Government UK. (2018). The future relationship between the United Kingdom and the European Union (CM 9593). London: Her Majesty's Government.

Hix, S., Hagemann, S., \& Frantescu, D. (2016). Would Brexit matter? The UK's voting record in the Council and the European Parliament. Re- 
trieved from http://eprints.Ise.ac.uk/66261/1/Hix Brexit matter_2016.pdf

Hopkin, J. (2017). When Polanyi met Farage: Market fundamentalism, economic nationalism, and Britain's exit from the European Union. The British Journal of Politics and International Relations, 19(3), 465-478.

Howarth, D., \& Quaglia, L. (2017). Brexit and the single European financial market. Journal of Common Market Studies, 55(S1), 149-164.

Howarth, D., \& Sadeh, T. (2010). The ever incomplete single market: Differentiation and the evolving frontier of integration. Journal of European Public Policy, 17(7), 922-935.

Inagaki, K., Lewis L \& Mace H. (2019). Sony to shift European domicile from UK on Brexit risk. Retrieved from https://www.ft.com/content/e11ddf32-1edb11e9-b126-46fc3ad87c65

Innes, A. (2018). The new crisis of ungovernability. In B. Martill \& U. Staiger (Eds.), Brexit and beyond: Rethinking the futures of Europe (pp. 138-146). London: UCL.

Irwin, G. (2015). Brexit: The impact on the UK and the EU. Global Council. Retrieved from https:// www.global-counsel.co.uk/analysis/special-report/ brexit-impact-uk-and-eu

Jones, E., Kelemen, R. D., \& Meunier, S. (2016). Failing forward? The Euro crisis and the incomplete nature of European integration. Comparative Political Studies, 49(7), 1010-1034.

Joulaud, M. (2019). Written question support for regions affected by Brexit. European Parliament. http://www.europarl.europa.eu/doceo/document/ P-8-2019-001152_EN.html

Keleman, D. (2007). Built to last? The durability of EU federalism. In T. Boerzel \& S. Meunier (Eds.), State of the European Union (pp. 51-66). Oxford: Oxford University Press.

Lagenbacher, E. (2017). Tschüss, Perfidious Albion: German reactions to Brexit. German Politics and Society, 35(3), 69-85.

Levell, P. (2018). Firms' supply chains form an important part of UK-EU trade: What does this mean for future trade policy? London: Institute Fiscal Studies.

Lomas, U. (2018). Dutch firms face substantial Brexitrelated tax costs: KPMG. Tax-News. Retrieved from https://www.tax-news.com/news/Dutch_Firms_ Face_Substantial_BrexitRelated_Tax_Costs_KPMG_ 76268.html

Lowe, S. (2018). Brexit and rules of origin: Why free trade agreements $\neq$ free trade. London: Center for European Reform. Retrieved from https://www.cer. eu/insights/brexit-and-rules-origin-why-free-tradeagreements- $\neq$-free-trade

Luyendijk, J. (2016). Brexit is great news for the rest of the EU. The Guardian. Retrieved from https:// www.theguardian.com/commentisfree/2016/jun/ 28/brexit-great-news-eu-britain-sovereignty

Maxwell, F. (2018). Netherlands to hire 750 extra customs officials to tackle Brexit. Retrieved from https://www.politico.eu/article/brexit-netherlandsto-hire-750-extra-customs-officials-to-tackle

Monti, M. (2010). A new strategy for the single market: At the service of Europe's economy and society. Retrieved from http://cms.horus.be/files/99931/ Newsletter/MM\%201\%20-\%20Single-Market-NewStrategy-Monti-Report-09.05.10.pdf

Rhodes, C. (2018). Financial services contribution to the UK economy (Briefing Paper No. 6193). London: House of Commons.

Ruggie, J. (1982). International regimes, transactions, and change: Embedded liberalism in the postwar economic order. International Organization, 36(2), 379-415.

Schelkle, W. (2018). What impact will Brexit have on the euro area? In B. Martill \& U. Staiger (Eds.), Brexit and beyond: Rethinking the futures of Europe (pp. 124-131). London: UCL.

Thompson, H. (2017). Inevitability and contingency: The political economy of Brexit. British Journal of Politics and International Relations, 19(3), 434-449.

van Nistelrooij, L., \& Joulaud, M. (2018). EU regions affected by Brexit should not be left behind. Euractiv. Retrieved from https://www.euractiv.com/section/ economy-jobs/opinion/tue-eu-regions-affected-bybrexit-should-not-be-left-behind

Weatherill, S. (2017). The several internal markets. Yearbook of European Law, 36, 125-178.

Wright, W., \& Bax, L. (2016). What do EU capital markets look like post-Brexit? London: New Financial. Retrieved from https://newfinancial.org/wp-content/ uploads/2016/09/2016.09-What-do-EU-capitalmarkets-look-like-post-Brexit-a-report-by-NewFinancial.pdf

\section{About the Author}

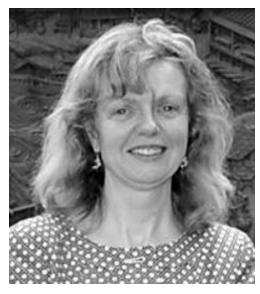

Michelle Egan is Professor and Jean Monnet Chair, School of International Service, American University. She is CFR Fellow (IAF) 2018-2019 and is a Global Fellow at Wilson Center. She has published several university press books and peer-reviewed articles on the European, US and Canadian single markets, transatlantic relations, EU law, federalism and trade. Her current research is on Canadian trade policy, Brexit and single market, and contestation in liberal trading order. 